Article

\title{
Socio-Spatial Segregation and the Spatial Structure of 'Ordinary' Activities in the Global South
}

\author{
Pablo Muñoz Unceta ${ }^{1}$, Birgit Hausleitner ${ }^{2, *}$ and Marcin Dąbrowski ${ }^{2}$ \\ ${ }^{1}$ FabLab Barcelona, Institute for Advanced Architecture of Catalonia, 08005 Barcelona, Spain; \\ E-Mail: pablo.munoz@iaac.net \\ 2 Faculty of Architecture and the Built Environment, TU Delft, 2628 BL Delft, The Netherlands; \\ E-Mails: b.hausleitner@tudelft.nl (B.H.),m.m.dabrowski@tudelft.nl (M.D.) \\ * Corresponding author
}

Submitted: 30 March 2020 | Accepted: 29 May 2020 | Published: 31 August 2020

\begin{abstract}
Planning practice in the Global South often defines a border between formal and informal developments ignoring the complex and nuanced reality of urban practices and, consequently, worsening segregation. This article proposes an alternative view of socio-spatial segregation that shifts the distinction between formal/informal towards one that emphasises access to opportunities and their relationship with the spatial structure of the city. Under this alternative framework, applied to the case of the Valle Amauta neighbourhood in Lima, Peru, we reflect on how socio-economic activities, shaped by spatial conditions and social practices, increase or reduce socio-spatial segregation. Our findings suggest that a shift towards strategies aimed at increasing accessibility to centrality, provided by the density of social and economic activities, could offer new opportunities for planning practice and theory in the Global South.
\end{abstract}

\section{Keywords}

informality; Global South; segregation; spatial justice; urban morphology

\section{Issue}

This article is part of the issue "Cities of Inclusion-Spaces of Justice" edited by Anja Nygren (University of Helsinki, Finland) and Florencia Quesada (University of Helsinki, Finland).

(C) 2020 by the authors; licensee Cogitatio (Lisbon, Portugal). This article is licensed under a Creative Commons Attribution 4.0 International License (CC BY).

\section{Introduction}

Socio-spatial segregation is a phenomenon in which space is organised "in areas of strong internal homogeneity and strong social disparity between them" (Castells, 1977). It expresses relationships of exclusion, subjection or inferiority (Marcuse, 1997) between different social groups in space. These groups may be defined by income, ethnicity, age or any other socio-economic characteristics. It takes place in many cities and regions around the world (Aguilar \& Mateos, 2011; Marcuse, 1997; Sabatini, 2006), but especially in those with deep social differences (Watson, 2006).

In many cities in the Global South, 'formal' and 'informal' categories are often used to steer and control urban development. The term 'informality' was origi- nally coined to describe practices that do not have a place in the formal economy and the official set of rules and laws (International Labour Office, 1972). In the context of urban development, informality often refers to a complex and ambiguous process of development that takes place outside of the norm and often (but not always) ignores building regulations (Herrle \& Fokdal, 2011). In Latin America, informality is often connected to the intense rural-urban migrations that led to explosive urban growth during the 20th century. The areas where vulnerable migrants settled were often labelled as informal in official planning and policy (Calderón, 2014). This labelling is a premeditated gesture aimed at stigmatising the city-making process taking place outside of the 'formal' hegemonic state institutions (Delgado, Peek, \& d'Auria, 2019) and excluding people in these areas from 
the right to property (Calderón, 2016, p. 76), in order to justify the policies and planning instruments focused on the 'formalisation' of those areas (Roy, 2005), upgrading or, in some cases, clearance and replacement with new developments (Watson, 2016).

These measures often reinforce the formal/informal dichotomy either by overlooking the intrinsic characteristics of urban space (McCartney \& Krishnamurthy, 2018) or by displacing people. Socio-spatial segregation of vulnerable groups in informal-labelled areas excludes them from material means, services and opportunities, or from decision-making processes (Smets \& Salman, 2016). This, in turn, reduces their possibilities to overcome poverty or to meet their basic needs. At the same time, this formal/informal dichotomy results in a misunderstanding of the genesis and everyday realities of segregated and deprived neighbourhoods in the Global South, which, in reality, remain intertwined with formal processes (Delgado et al., 2019). Against this background, informality should be understood "not a separate sector but rather a series of transactions that connect different economies and spaces to one another" (Roy, 2005, p. 148). In this study, we echo these arguments and provide novel evidence to underpin a new perspective on segregation going beyond the formal/informal dichotomy by exploring (1) how 'ordinary' socio-economic activities in deprived neighbourhoods transgress the boundaries between areas developed in an informal or formal way, and (2) how spatial configurations facilitate or hinder those activities. For Fainstein (2011, p. 3), a just city would be "a city in which public investment and regulation would produce equitable outcomes rather than support those already well off." Nevertheless, mechanisms of redistribution of resources and political representation studied in spatial justice theory often come from a Western tradition and remain difficult to apply in contexts of deep inequality (Watson, 2006), where institutions, activities and agreements do not always follow official rules. Alternative developments also produce different spatial characteristics to those usually studied in urban morphology theory (McCartney \& Krishnamurthy, 2018).

Moreover, the planning distinction between socalled formal and informal developments associates informality with specific areas of the city rather than with urban practices that have a bearing on inequality. In planning practice, socio-spatial segregation is thus mostly approached from a property and land rights perspective, assuming that a change in the status of land would promote integration of its inhabitants. This article proposes to shift the lens away from informality and focuses on how access to opportunities helps overcome socio-spatial segregation. Opportunities are related to social, economic, or political activities in the city that are shaped by the features of the spaces in which they happen (Habraken, 2000).

Access to opportunities in many cities of the Global South is also enabled by different mechanisms than those usually implemented in traditional Western planning and policies and studied in spatial justice literature. As Ruiz-Tagle (2016) argues for the Chilean case, integration policies often focus on territorial dispersion and access to land rather than on the redistribution of opportunities and resources. The former, often used in European planning and housing policies (Giffinger, 1998) is often insufficient to overcome socio-spatial segregation in other parts of the world. Redistribution of resources, on the contrary, may involve actors and responsibilities different from those usually included in Western policies. For example, the community redistributes opportunities, including the use of land, water or communal work in rural areas of Andean contexts (Dollfus, 1991; Malengreau, 1992), collectively managing a delimited physical space. This is also reproduced in urban contexts by migrant groups (Golda-Pongratz, 2007; Matos, 2012) and populations who face precariousness and scarcity of resources in cities. Similarly to rural communities, communal practices and community management of resources in urban areas take place in collectively owned land when individual land rights were not yet acquired (Salcedo, 2010). These spaces, in contexts developed outside official planning rules, also operate differently, limiting the explanatory power of urban morphology theory produced in the West (McCartney \& Krishnamurthy, 2018). Against this background, this article explores the following research question: how does the intersection of socioeconomic activities and spatial conditions increase or reduce socio-spatial segregation in deprived neighbourhoods that tend to be labelled as informal?

Using insights from the literature on the Global South, a case study of Valle Amauta, Lima, as well as examples of practices from other neighbourhoods in Lima, this article identifies the specific links between spatial features and socio-economic opportunities. The alternative approach proposed here aims at understanding the endogenous potential of the territory and the sociospatial practices embedded in cities of the Global South advocating a shift of focus in planning and policy from land formalisation and traditional housing provision to upgrading the spatial potential linked to the density of social and economic activities.

\section{Towards an Alternative Framework to Understand Socio-Spatial Segregation}

Spatial justice literature (Fainstein, 2011; Soja, 2013) offers a critique of urban development understood as a pursuit of growth and competitiveness, proposing an alternative perspective based on the need to promote the right to the city and, in particular, to make the distribution of benefits and burdens of urbanisation more equitable, paying more attention to how the access to resources and decision-making is distributed across space, and focusing on how it affects the most deprived social groups and areas, including socio-spatial segregation. Fainstein (2011), building on the cases of Amsterdam, 
London and New York, explored the policies and planning practices that favour the three hallmarks of what she calls a "just city"-equity, diversity and democracy. These range from the provision of social housing, zoning that prevents discrimination, land-use that promotes porosity between neighbourhoods and interactions between social groups, progressive transit fares, access to public space or engagement of disadvantaged groups in decision-making. The focus here is on what public authorities can do to promote spatial justice, in terms of equitable distribution of access to public goods and negative externalities of urbanisation as well as of access to democratic processes of decision-making in the context of a (Western) capitalist socio-economic system.

Both spatial justice and socio-spatial segregation, however, require some adaptation for application outside of the Western context. It has been argued (Aguilar \& Mateos, 2011; Salcedo, 2010) that socio-cultural distance may be more important to socio-spatial segregation than physical distance in Latin America. Having access to land or property rights is not enough to avoid exclusion when there is a big gap in economic, political, cultural or symbolic capital (Ruiz-Tagle, 2016). In fact, one needs to consider the socio-spatial reality in contexts of 'deep difference' (Watson, 2006, 2016). The latter refers to profound material or cultural inequality and the predominance of informal urban processes (Robinson, 2006; Roy, 2005). Such processes are especially relevant in relation to the stakeholders and practices (activities) that provide access to material or immaterial means guiding urbanization processes in the face of the weakness of the state. Examples of such bottom-up practices in Lima's deprived neighbourhoods include collective 'survival activities' such as the organisation of social dining rooms or communal construction of local infrastructure (Calderón, 2016; García Naranjo, 1992). Thus, 'access to opportunities' in such a context is determined by access to economic and social activities (Robinson, 2006), regardless of whether these are provided by the state, private or civil society actors. This access, in turn, is shaped by the place-specific socio-spatial conditions in which these 'everyday life' or 'ordinary' activities take place, calling for a more nuanced understanding of how the spatial morphology of deprived neighbourhoods (often labelled as informal areas) creates conditions for these activities.

The field of urban morphology describes, defines and theorises knowledge on form and formal change (Scheer, 2016) and suggests how it relates to the socio-economic conditions of a place. Vernez Moudon (1997) considers form, resolution and time as three basic components of morphological studies. Three main elements of form can be distinguished: streets, plots and buildings (Kropf, 2009; Scheer, 2016; Vernez Moudon, 1992). The resolutions are building, plot, block, street, city and region. How the main spatial elements are organised on the different resolutions explains how the organisation of the physical elements together is governed by territorial rules (Habraken, 2000). In other words, the organisation of spatial elements determines the control over space, which comes not only from ownership of land, but also from the appropriation of land by everyday activities that modify it.

The 'urban structure' of 'everyday environments' developed in 'self-sustaining' growth processes and its understanding is shared by the people of a place. The everyday environment can be observed by describing and analysing the relation between the location of activities, the control and form of a specific place. Understanding 'ordinary' everyday environments, means acknowledging a diversity of urban economics and dynamics of spatial settings. This is, according to Robinson (2006, p. 162), of higher relevance "in contexts with substantial levels of informality in economic practices." This means that the spatial reading common in Western analytic practisesbased on streets, plots, and buildings-is not enough to understand the dynamics of a place in the Global South. Despite being subdivided into plots, land in many urban settlements throughout Lima is not privately owned and managed collectively until individual land rights are obtained. The border between private and public spaces in these settlements is often blurred by 'survival activities,' such as community breakfast services for children that take place in private kitchens (García Naranjo, 1992). Nevertheless, plot formalisation, working as a commercial unit of individual land control, often weakens social organisation (Malengreau, 1992). The understanding of appropriation of space, and how it influences what is dynamic and what is stable for a longer duration, is essential. Unclear property boundaries that are constantly changing in so-called informal areas, lead to blurry borders that have an effect on where and what activities can take place. The unbuilt spaces of blurred ownership can become a "negotiated movement" (McCartney \& Krishnamurthy, 2018, p. 8), enabling access to otherwise inaccessible places and therefore providing new opportunity spaces. Further, building typology should be defined by the permanence of the built and unbuilt form, which depends on the level of investment in housing and security of tenure (McCartney, 2012).

For McCartney and Krishnamurthy (2018, p. 9), "within informal areas, a lot line or a boundary is a result of negotiations between a space's inhabitants rather than a formal contract." This is a key difference to Western morphological studies, which follow the precise boundaries and delineations of the built and unbuilt, as formalised on plans, questioning the transferability of solutions from areas developed with formal conditions towards those developed without standardised norms in plans. Without an understanding of the practices and decision-making processes of local communities, there is a risk of oversimplifying the specific qualities of space and overlooking existing opportunities based on these local practices and activities.

The current approach to socio-spatial segregation in deprived neighbourhoods, labelled as informal areas, very often and in many countries, neglects the role of 
spatial features as a factor preventing or deepening segregation and focuses on the role of the State in setting the conditions to 'integrate' areas under the jurisdiction of official urban regulation and 'formal' development. Policies tend to focus on economic regulations and formalisation of ownership as a mechanism to overcome poverty and, therefore, positively influence segregation. This often operates under the assumption that the economy operates similarly in different parts of the world, despite the social and cultural context. In Lima, regularisation in itself has been criticised for being insufficient to create opportunities and foster development in low-consolidated areas (Fernández-Maldonado, 2015). Moreover, the properties of specific spatial features are often assumed to be similar everywhere, neglecting the specificity of urban development happening outside the 'norm' and, therefore, displaying different spatial characteristics (McCartney \& Krishnamurthy, 2018). Against this background, an alternative approach to socio-spatial segregation that considers the specific opportunities brought by a different type of urban development is needed. The approach proposed in this article aims at understanding these opportunities by looking at the interconnections between its specific social and economic activities and the specific spatial conditions, and how these two are tied to the decisions that shaped the alternative (i.e., not sanctioned by the State authority) urban development process (Figure 1).

\section{Case Study Selection and Data}

\subsection{Case Study Selection}

In order to explore the potential of this alternative framework, a case in Lima, Peru, was selected. In Lima, relationships between formal and informal activities in urban development happen both in high- and low-income areas. Land-trafficking and other illegal activities have created a very lucrative business both in affluent and poor areas, usually bringing new and deep inequalities. These new economies are completely intertwined with formal processes, administrative and regularisation actions (Calderón, 2016), often blurring the line between formal and informal practices.

The case selected for the analysis, Valle Amauta (Figure 2), in Ate district in East Lima, was chosen because, firstly, there are different socio-economic groups living in segregated homogeneous areas (Instituto Nacional de Estadística e Informática [INEI], 2016). This segregation pattern is similar to many other areas of the city. Secondly, urban development in Valle Amauta started in the 1980s and many of its smaller settlements are currently under a regularisation process. Formalised areas coexist with areas that attempt to formalise individual land tenure ship. Thirdly, Valle Amauta is often the object of specific policies that target so-called informal areas, e.g., the Barrio Mío slum upgrading program (Municipality of Lima, 2013b). Therefore, a comparison between the two approaches described in a theory review is possible. Lastly, detailed GIS cadastral data was developed in 2016 by the Municipality of Ate District and the Inter-American Development Bank. In addition, documented cases from other similar areas of the city are used to complement the analysis in Valle Amauta and present examples of how social and economic activities matter for overcoming segregation.

\subsection{Variables}

The variables used in this analysis reflect both the current and the proposed approach to socio-spatial segregation. Under the current approach, the socio-economic profile of the population is linked to informality and property. Access to better life conditions (less vulnerability) is granted by access to formal property. Meanwhile, the alternative approach, considers social and economic ac-

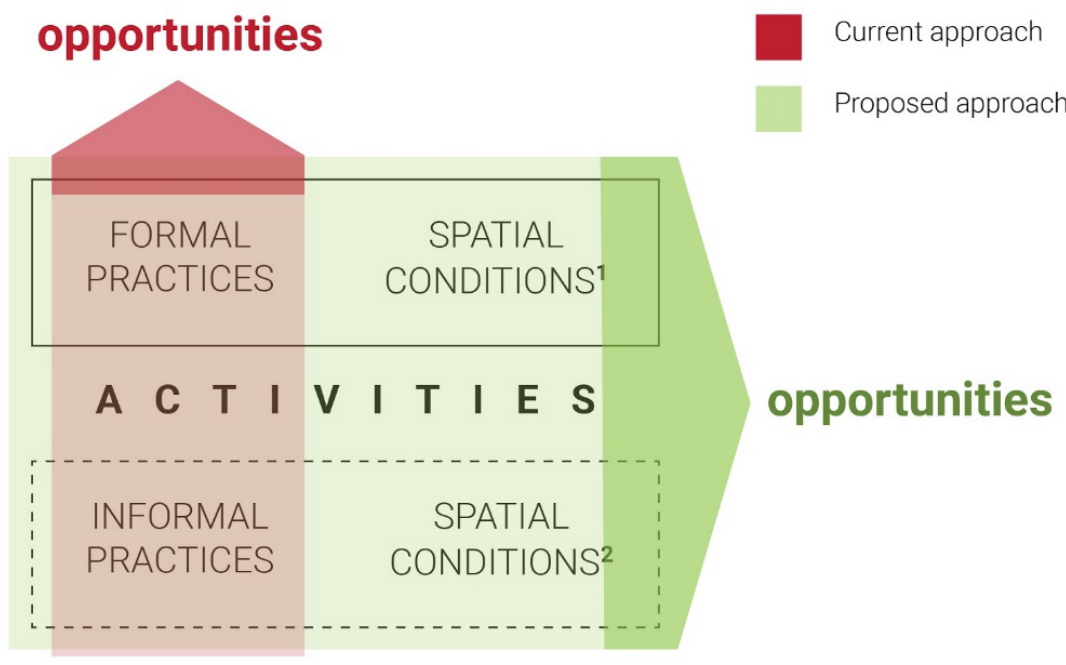

Figure 1. Existing and proposed approaches on socio-spatial segregation. Source: Authors. 


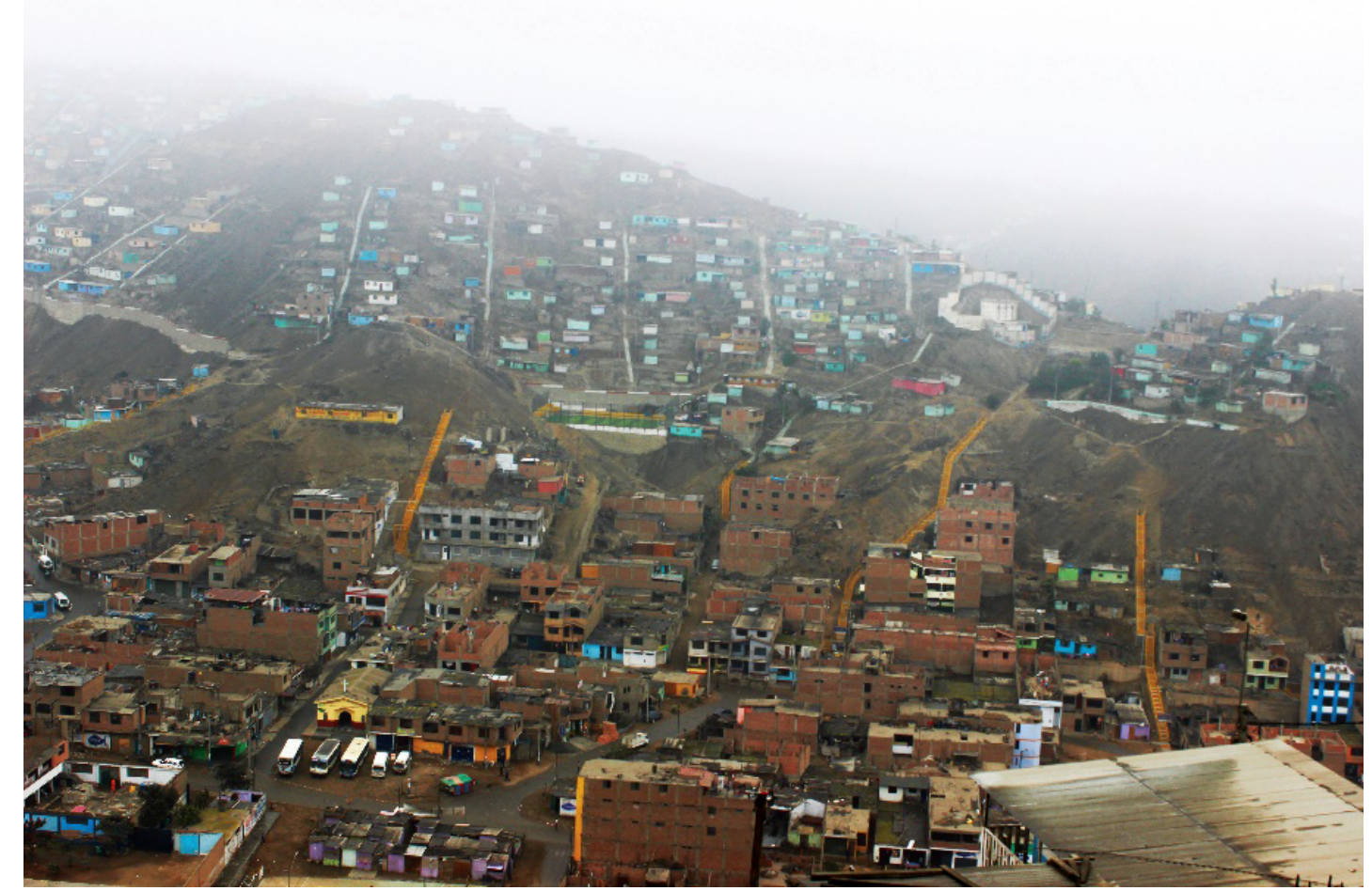

Figure 2. A view of Valle Amauta. Source: Authors.

tivities as well as contextual and spatial variables. The variables of the decision-making process and topography are given, according to the context. The spatial variables of centrality, plot size and Floor Space Index are three variables known to be linked to socio-economic activities (Chiaradia, Hillier, Schwander, \& Wedderburn, 2009; Hausleitner \& Berghauser Pont, 2017; Hillier \& Hanson, 1984; Sevtsuk, 2010; van Nes, 2005). Thus, the analysis used variables as described in the following sections.

\subsubsection{Spatial Variables}

- Centrality: Centrality describes "how the line is positioned with respect to the system as a whole" (Hillier, 1996, p. 119). Centrality, as measured here by 'angular choice,' is calculated by "how often a line falls on the shortest path between all pairs of lines in a network" (PST Documentation, 2019), being every path counted once for every direction. It thus defines how many shortest paths pass through a street segment, which describes possible movement flows in cities (Hillier \& lida, 2005). Mapped based on Open Street Map (2019) edited and completed for the case study area.

- Plot size: The total area of land comprised between the borders of a plot in square metres (sqm). The plots are the spatial property of basic land division (Whitehand, 2001), their size is the spatial property that influences building form (Siksna, 1997) and indicates the potential for "diverse users and owner strategies" (Berghauser Pont et al., 2019). Plot size is one of the variables that determine pop- ulation density in a neighbourhood, along with the number of houses per plot. Data from GIS Cadastre of Ate District (Municipality of Ate, 2016).

- FSI (Floor Space Index): The number of built sqm in relation to the plot size in sqm. The distribution of buildings on plots expressed in built density influences the number of people or activities that can be accommodated on the plot. FSI is an indicator of how consolidated a plot is in terms of built density. The higher the FSI, the more investment in construction has taken place. Data from GIS Cadastre of Ate District (Municipality of Ate, 2016).

\subsubsection{Socio-Economic Variables}

- Activities: Points per activity location. Social and economic activities that provide opportunities for collective (social organisation, healthy food or childcare) or individual development (economic profit, family house construction). Data from schools' data (Ministry of Education of Peru, 2019) and economic activities' data (INEI, 2019).

- Vulnerability: Average income per person by household. Vulnerable groups are defined according to the socio-economic scale developed by INEI (2016). This scale goes from A (high income) to D (low income) and is defined according to education, social status and economic wealth.

- Informality: For the maps, official spatial boundaries of 'informal' areas defined by the Informal Property Formalisation Organism (COFOPRI) and the delimitation of 'informal' land development ac- 
cording to the Municipality of Lima (2013a) are used. Informality is understood as a process taking place outside of the norm (Herrle \& Fokdal, 2011). The analysis on the current approach uses Calderón's (2016, p. 76) understanding of 'informal' areas as places in which people "are excluded from the right to property and whose situation must go through a process of regularisation." Based on COFOPRI's data in 2013 (Municipality of Lima, 2013b).

\subsubsection{Contextual Variables}

- Topography: The given difference of height in the territory. Given that Lima is located in a valley, many factors are influenced by topography. Accessibility for mobility systems, the possibility to implement infrastructure (water, sewage, roads), the cost of delivering building materials or the exposure to risk. These factors influence where different types of activities take place. Data from Ministry of Environment of Peru (2019).

- Decision-Making Process: Cultural, normative, and social context for ongoing urban development. The power and interest balance of different stakeholders influences decisions on where, how and what is developed in a neighbourhood. The decision-making process is described using examples or micro-stories of specific urban processes in Valle Amauta. Data gathered from fieldwork and interviews (Muñoz Unceta, 2019).

\section{Analysis}

\subsection{Context}

In Valle Amauta and many other parts of the city, borders between so-called formal and informal areas have played, and still play, an important role in urban development. In Lima, policies have targeted differently areas that were labelled as formal and informal. Different laws, since 1961, have defined the regularisation process for so-called informal settlements, establishing the requirements for a settlement to transition from one category to the other, including proving possession of the land, its registration in the local municipality, holding an official risk assessment or having water, sewage and electricity networks implemented, among others (Congreso de la República del Perú, 2006, 2015). According to this process, urban upgrading programs such as A Trabajar Urbano (2002-2006), Agua para Todos (2007-2013) or Programa de Mejoramiento de Barrios (2004-present) implemented urban infrastructure in low-income areas and developed outside the norm. These programs remained fragmented and uncoordinated due to the barriers created by the administrative boundaries and formal/informal labelling of neighbourhoods (Espinoza \& Fort, 2017). Meanwhile, urban regulation and zoning plans have been the main instruments to steer the process of urban development in areas designated as 'formal.'

In both sets of regulations, property was not only a central issue that defined the approach of policies, but also determined where policies and programs were applied (Calderón, 2016). Some urban upgrading programs only target settlements that are considered 'formal', while others focus on the infrastructure needed for formalisation. Ownership was also influenced by whom and how the land was developed. Figure 3 shows the official differentiation of 'formal' or 'informal' areas according to the initial process of land development (Municipality of Lima, 2013a). Private property dominated in central areas of the city, whereas development labelled as 'informal' tended to be located on public land (Fernández de Córdova, Fernández-Maldonado, \& del Pozo, 2016), often in the least accessible places on the fringes of the city. Property was thus used to define and tackle the problem. Formal and informal labelling of areas both influenced the current gradient of socio-spatial segregation and provided a framework for policies addressing it.

\subsection{Discrepancy between Scales; or the Need to Look Closer}

Formal and informal borders, however, do not correlate with the location of socio-economic groups or the centrality structure of a neighbourhood on a smaller scale. Whether an area went through a formalisation process or not, does not necessarily imply in itself a better opportunity for social or spatial development. This is observed in Valle Amauta (Figure 4), where many of the so-called 'formal' areas host both vulnerable and very vulnerable populations, while showing different degrees of centrality and spatial integration. At the scale of Valle Amauta, the official definition of formal and informal areas, based on the requirements needed for formalisation, does not provide an accurate lens to understand socio-spatial segregation: spatial integration and vulnerability are similarly observed on both sides of the official formal border.

The spatial centrality structure, similar to segregation seen through multiple scales, also differs depending on the radius of the area analysed (Figure 5; Vernez Moudon, 1997). Mapping is used to visualize and compare spatial characteristics, such as the structure of the street network or the size of plots, through different scales.

\subsection{The Interconnection between Activities and Spatial Conditions}

In the following cases, the location of hardware shops, hotels, schools and community activities in Valle Amauta is paired with spatial characteristics such as the integration of the street network, the FSI, the size of plots and the topography of the urban area (Figures 6 and 7). These types of activities showcase the relationship between the decision-making process, the spatial characteristics 


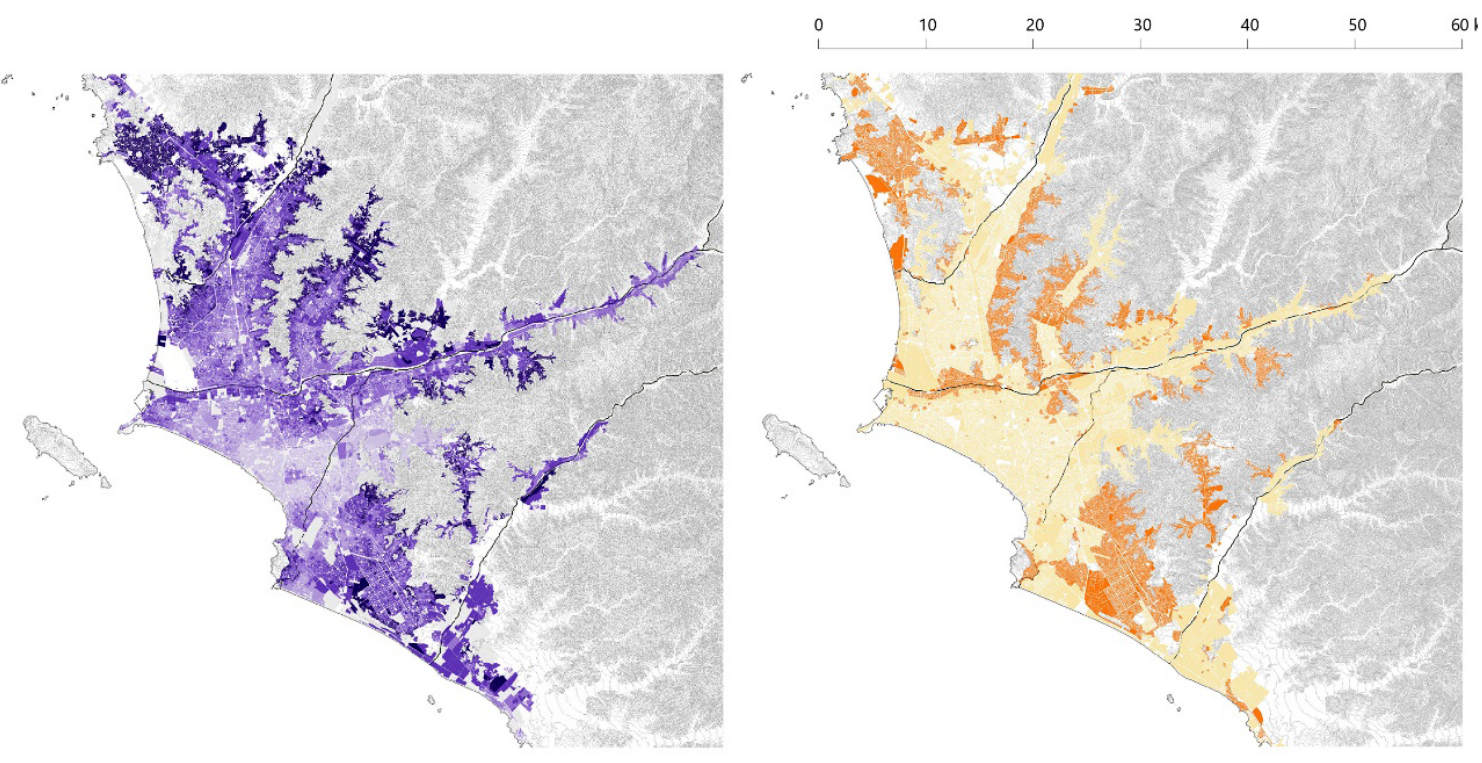

Socioeconomic groups in Metropolitan Lima $E$ is the most vulnerable sector

Type of urban development

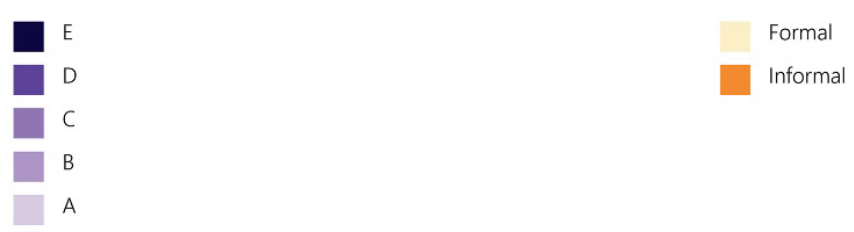

Figure 3. Distribution of socioeconomic groups and areas labelled as informal and formal in Metropolitan Lima. Source: Authors, based on data from INEI (2016) and Municipality of Lima (2013a).

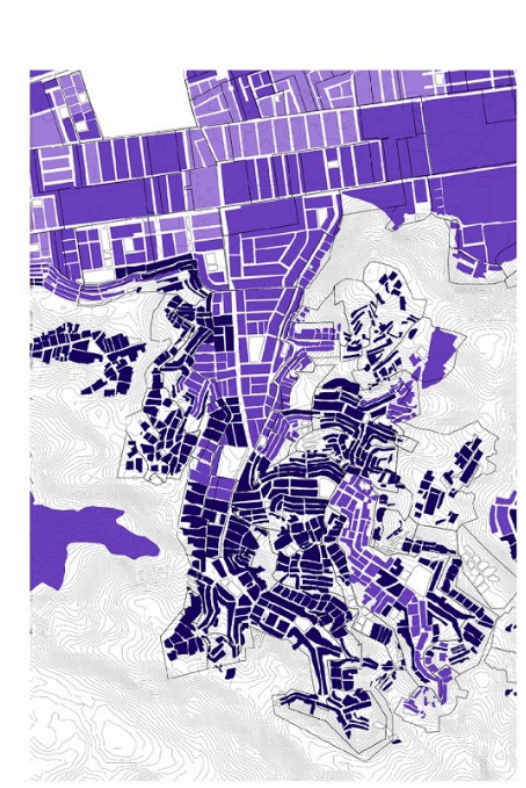

Socio-economic groups Valle Amauta $\mathrm{E}$ is the most vulnerable sector

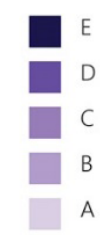

\begin{tabular}{lllll}
\hline & 500 & 1000 & 1500 & $2000 \mathrm{~m}$
\end{tabular}

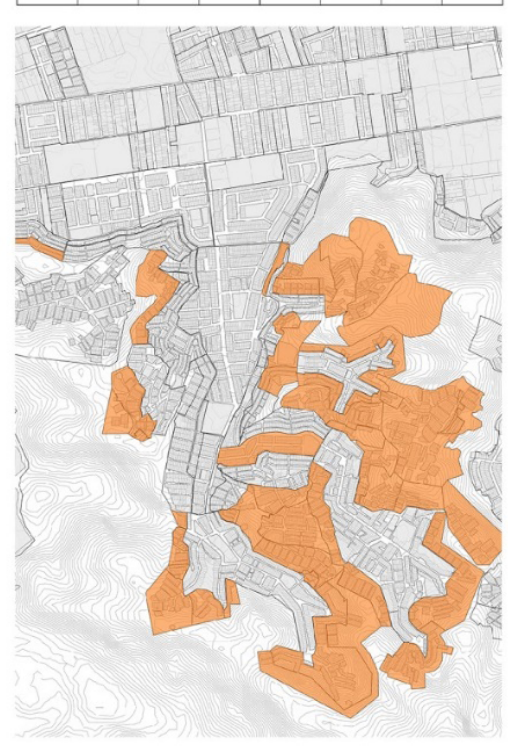

Settlements labelled as informal

Urban settlement borders

Current informal settlements

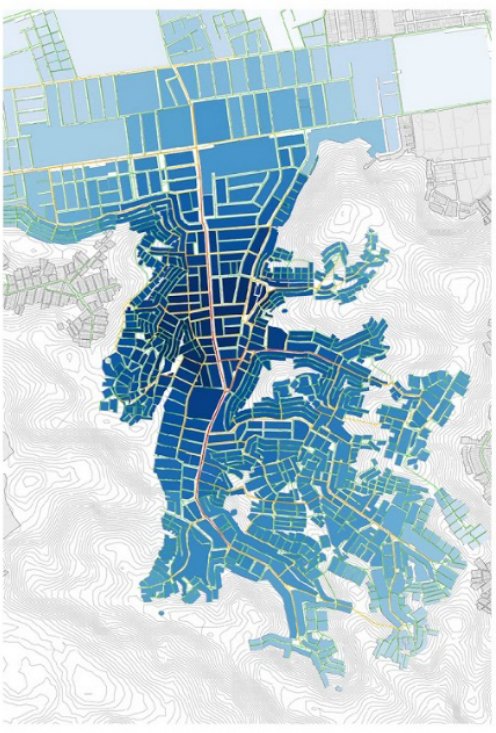

Local Spatial Integration Attraction reach plot to plot $(2 \mathrm{~km})$

High integrated

Low integrated

Figure 4. Socio-spatial segregation and urban informality in Valle Amauta. Source: Authors, based on data from INE (2016), Municipality of Ate (2016) and Municipality of Lima (2013b). 


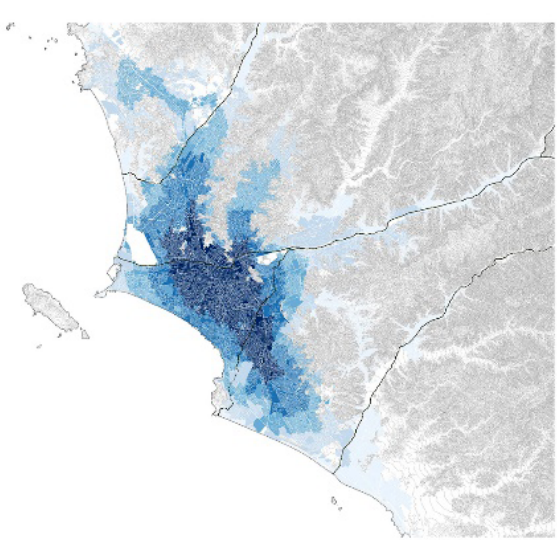

Metropolitan centrality Attraction reach plot to plot $(10 \mathrm{~km})$

High integrated

Low integrated
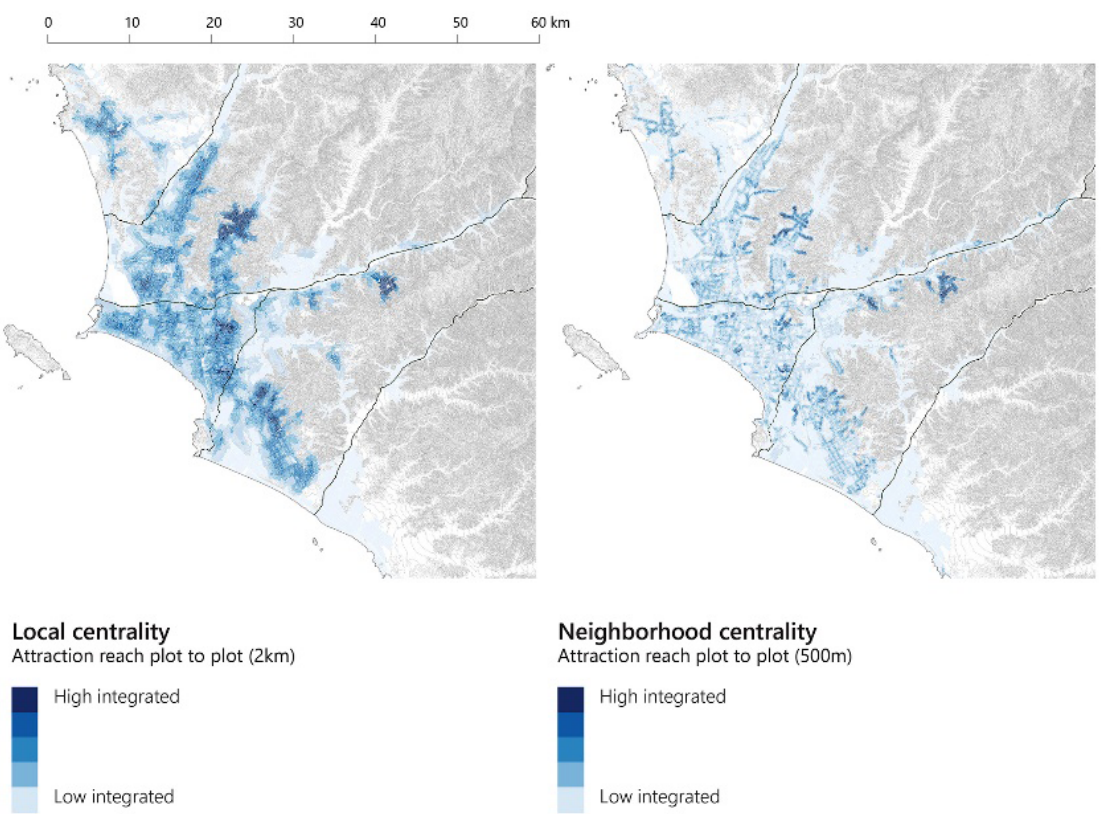

Neighborhood centrality Attraction reach plot to plot $(500 \mathrm{~m})$

High integrated

Low integrated

Figure 5. Relationship between the centrality structure and scale in Metropolitan Lima. Source: Authors, based on data from Municipality of Lima (2013a) and Open Street Map (2019).

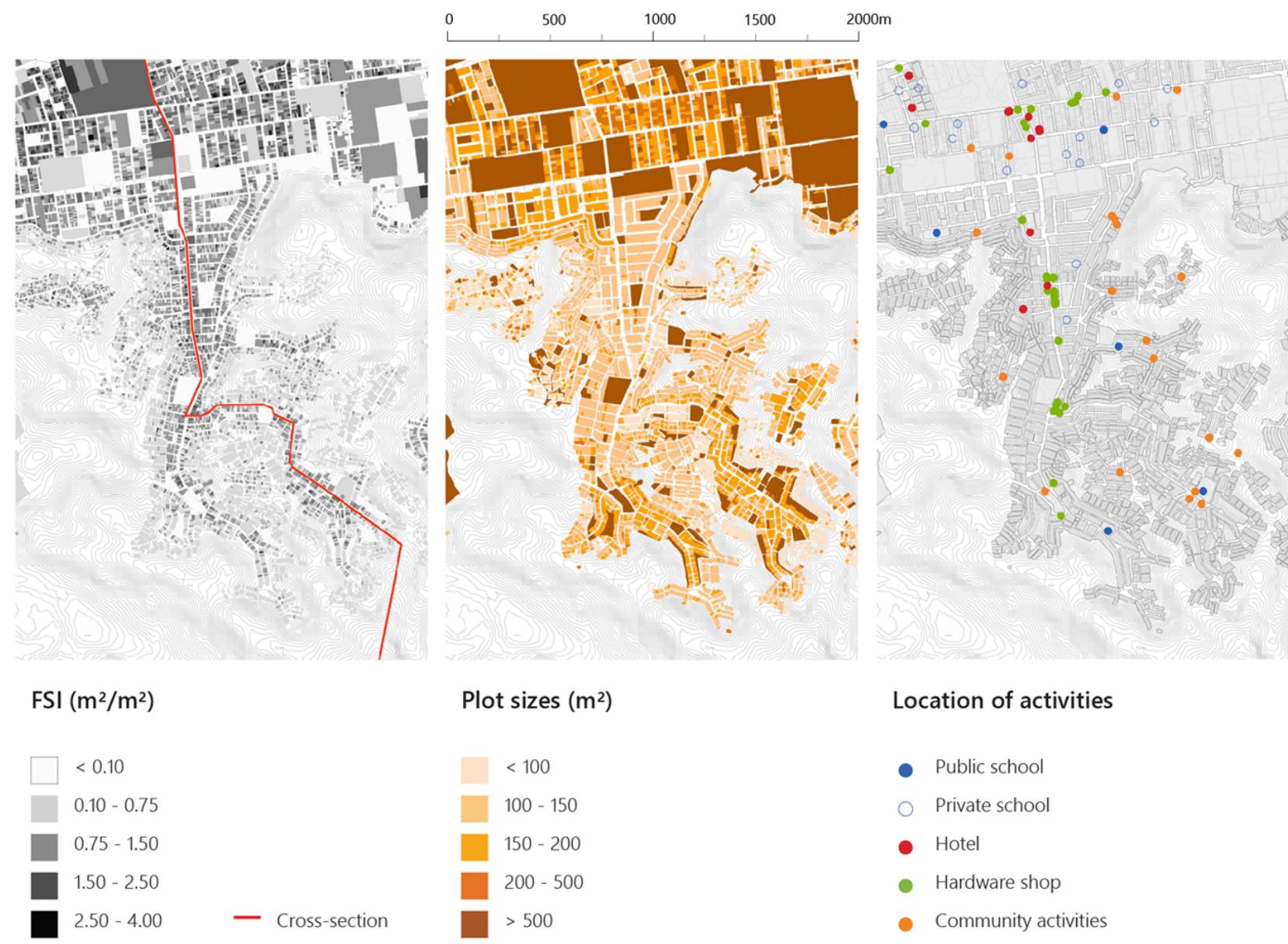

Figure 6. Spatial characteristics and activities in Valle Amauta. Source: Authors, based on data from Ministry of Education of Peru (2019), INEI (2019), Municipality of Ate (2016) and Municipality of Lima (2013b). 
and the activities themselves, providing an alternative lens to look at and tackle socio-spatial segregation.

Relationships through topography provide a basic framework to understand urban development and segregation in Lima. The formal city was mostly developed at the bottom of three river valleys. Flat areas were originally agricultural fields or, later, industrial areas owned by few families, who became land developers in time (Calderón, 2016, p. 118). At the other end of these valleys, the slopes gradually hosted a low-income population in so-called informal areas. The latest settlements were developed on the steep land of the periphery. In Valle Amauta, the location of social and economic activities also follows a rationale connected to their position in the cross-section of the slope and their accessibility (Figure 7). Profitable economic activities, such as hotels or hardware shops are located in semi-flat and high integrated areas, while areas less integrated and higher up on the slope have less value, and are therefore left for schools or community activities, which were also consolidated later in time. In the following, the main economic and community activities are described in their relation to the other variables.

Hardware shops are a very profitable business in Lima. Urban development in many areas starts with land occupation and is followed by progressive development of housing and services. Hardware shops usually become the main supplier of construction material for selfbuilders. They are usually located in highly integrated streets of semi-flat areas of the valley and even sometimes in the low areas (Figure 7). This advantageous position allows them to be reached by people from different areas of the neighbourhood. This type of activity is found in medium-size plots (100-150 sqm) among housing areas. Hardware shops are often highly consolidated buildings, with an FSI of 1.5 to $2.5 \mathrm{sqm} / \mathrm{sqm}$ (Figure 8). The income provided by this economic activity grants the shopowners money for the construction of new floors. These are often rented out as rooms or apartments, generating additional profit. This densification process usually takes place spontaneously, outside of the control of the State and often ignores housing regulations.

Young couples in Lima often live with their parents until they get married. Nevertheless, they need a place to have some intimacy. Hotels satisfy this necessity in many neighbourhoods. Hotels in Valle Amauta are located in areas that are highly integrated (Figure 6 ) and accessible by many people in the neighbourhood while offering enough anonymity not to be easily recognised by a neighbour or a relative. Hotels in Valle Amauta are developed in flat areas of the valley (Figure 7), which previously hosted industrial uses and where large-size plots (200 to 500 sqm; see Figure 8), despite being accessible, are not located in main streets. FSI is often high ( 0.75 to $2.50 \mathrm{sqm} / \mathrm{sqm}$ ), showing a higher built-density than other plots in the area. Hotels bring opportunities to other businesses, such as pharmacies or restaurants, clustering around them.

The decision on where public schools were located in Valle Amauta and many other neighbourhoods of Lima answers to economic criteria. Semi-flat areas of Valle Amauta were developed around the 1990s (Figure 7) without following urban regulation, thus fostering occupation first and then the construction of housing and

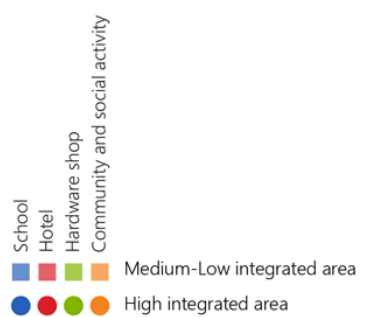

Distance 0
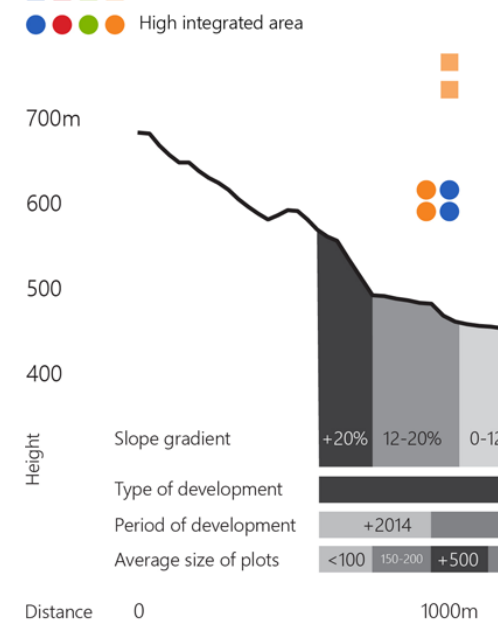

$\square$
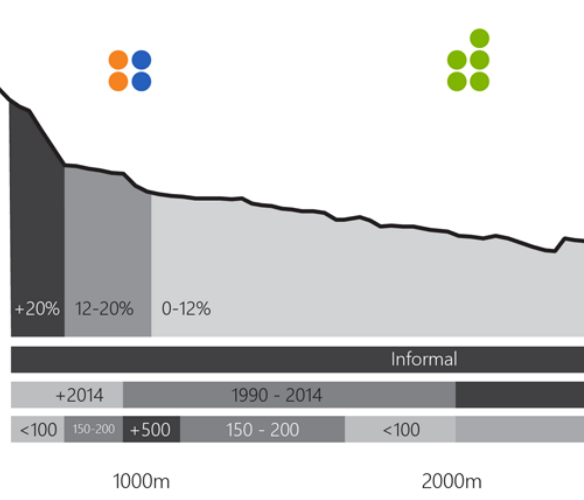

Figure 7. Spatial characteristics and location of activities in Valle Amauta on the cross-section. Source: Authors, based data from INEI (2019), Ministry of Education of Peru (2019), Ministry of Environment of Peru (2019), Municipality of Ate (2016) and Municipality of Lima (2013b). 

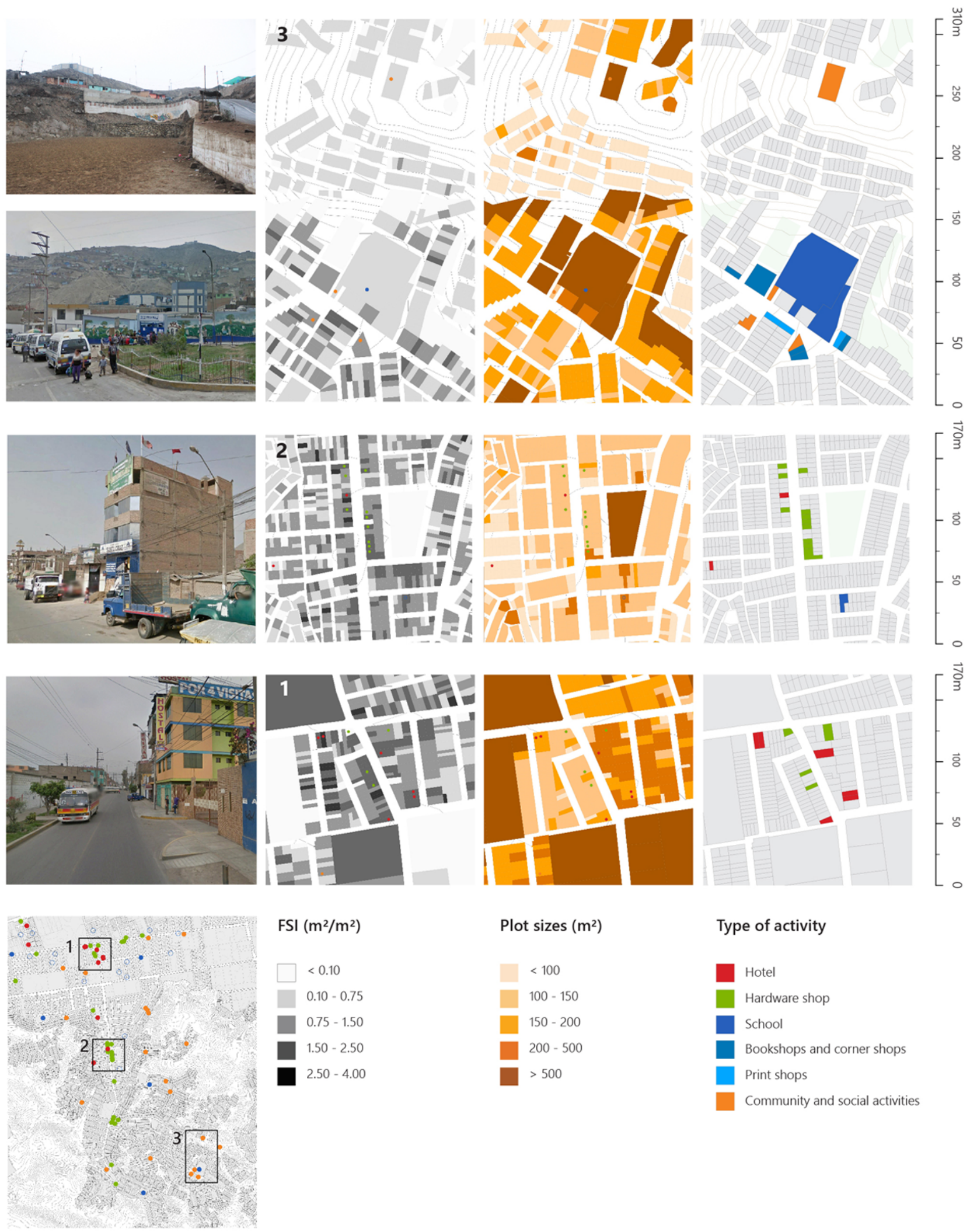

\section{Type of activity}

Hotel

Hardware shop

School

Bookshops and corner shops

Print shops

Community and social activities

Figure 8. Spatial characteristics for different types of activities in Valle Amauta. Source: Analysis and mapping by the authors with data from INEI (2019), Ministry of Education of Peru (2019), Municipality of Ate (2016), Municipality of Lima (2013b). Pictures from Google Street View (in 2013) and by the authors. 
the implementation of infrastructure and services second. This informal planning process designated land that was the furthest away, at the bottom of the steep slopes, for public facilities, whereas the lowest, most accessible and most profitable areas of the valley were developed as housing and commerce. Schools were nevertheless given big portions of land along a topographic 'fracture line' where the slope begins. These large and irregular portions of land were preserved under public management despite the most recent developments on the slopes, which extended the neighbourhood beyond the 'fracture line' and sometimes redefined and shifted the school border as a result of negotiations between the "space inhabitants" (McCartney \& Krishnamurthy, 2018). Schools remained at an intermediate height in the neighbourhood, becoming a second-tier centrality in low consolidated areas, drawing other economic and social activities, such as bookshops, print shops, corner shops or social services (Figure 8). These irregular portions of land, also delimited for public spaces and other low-benefit land-uses have, nevertheless a great potential to become integration spaces for people living on the steep slopes and to those staying in semi-flat areas, due to their intermediate location. Nevertheless, proximity of different social groups does not grant social cohesion (Ruiz-Tagle, 2016) and these potential integration spaces may have to consider activities that tackle political or cultural distance as well.

Social and community activities in Valle Amauta, such as collective dining rooms, NGOs, churches or nursery schools, are usually located in medium-to lowintegrated areas, close to very steep land (Figures 7 and 8). The same logic behind the low land value and the position of schools operates for community activities. Nevertheless, the size of plots differs for activities located in low-integrated areas (plot sizes from 150 to $500 \mathrm{sqm}$ ) to those located in semi-flat and medium integrated areas (less than $150 \mathrm{sqm}$ ). The latter are often clustered around schools or markets, which foster centrality in the fringes of topographic changes, while the former remain disconnected. In both cases, community activities present low FSI values ( 0.10 to 0.75 sqm/sqm; see Figure 8), and sometimes, especially in the case of open space or sports activities, plots have irregular shapes due to topography (Figure 8). Social and community activities located in recently developed areas are fostered by material scarcity and collective land management in areas without land titles, increasing territorial control over its immediate environment (Salcedo, 2010). Many of these activities, once the land tenure is formalised and individualised, change their nature or tend to disappear, similarly to what is observed in rural communities (Malengreau, 1992).

\subsection{Findings: Valle Amauta and Lima}

In sum, the presence of these activities is connected to decisions that aim for social or economic benefits and are influenced by spatial conditions. Activities do not cluster only in areas defined as formal, but they benefit from the size, position or interrelations of a place regardless of its property type and they answer to processes that connect areas across the formal/informal border. Formally recognised economic activities, such as hardware shops, benefit from houses that are progressively built in selfconstructed settlements and, at the same time, favour informal densification processes in formally tenured land. Public facilities, such as schools, provide centrality by acting as a social destination, which attracts other activities along the streets, both in areas on the slopes labelled as 'informal' and in semi-flat areas that tend to be labelled as 'formal.' Hence, the formal/informal border does not define access to opportunities. Instead, the connectivity between different activities influences access to opportunities.

Local centrality of places, determined by high connectivity between activities, is therefore a core characteristic that allows the generation of further opportunities. The consolidation of land, in terms of built density, differs between commercial and community activities, showing commercial opportunities in highly consolidated places, whereas community opportunities seem to appear in less consolidated places. The role of plot size remains still rather vague.

Despite the limitations of the current approach to formal and informal borders and illustrating the potential of the proposed framework, the extent to which activities and the spatial features that enable them to provide access to opportunities in Valle Amauta, would require further research, including empirical cases, interviews or case studies. The present article focuses on where and what activities were enabled by certain spatial characteristics in Valle Amauta. Who has access and in which way could not be analysed on the basis of the presented empirical material. Nevertheless, the following examples from similar neighbourhoods in Lima illustrate that: First, the border of former industrial areas in the Independencia district, which were initially owned by the Aliaga family, determined the location of El Ermitaño in 1962, one of the oldest large-scale informally developed areas in Lima (Bosio \& Renteria, 1985). The presence of large numbers of inhabitants along with the spatial characteristics of the former industrial area (big plot sizes, high metropolitan integration) fostered the redevelopment of some areas of Independencia district into a thriving economic cluster based around 'love hotels.'

Second, Huaycán, an occupation of land led by civil society organizations and the Municipality of Lima in 1984 in the East of the city, followed a spatial and social scheme structured around housing units. Each of them hosted sixty families, who would decide the shape and organization of plots and streets in a 1-hectare piece of land following two rules: two perpendicular streets would always cross the housing unit and plots could not be bigger than 90 sqm (Figari, 1986). These spatial guidelines, along with the density of the housing unit (number 
of families per hectare), have provided opportunities for small businesses benefiting from the density of people and the interconnected street-network. The third example, Horacio Zevallos, a neighbourhood which was developed at the same time as Huaycán a few hundred metres closer to the city of Lima, allowed lower densities and bigger sizes of plots. Central areas of Horacio Zevallos, compared to central areas in Huaycán, have created a dormitory city, where not much economic activity is seen (Godiño \& Sulca, 2017) (Figure 9).

Finally, La Balanza, a neighbourhood in the high slopes of Comas district in the North of the city, has been an example for an urban regeneration process that has benefited from the connection of different social activities. An existing social dining room, managed by a group of women, was the scenario for spatial improvements that allowed other activities to share that space. A second floor was built and used by cultural and theatre associations in the neighbourhood to rehearse and present their work. The public space was improved for sports, new green areas and a skatepark were developed, and improved streets and public staircases connect this spot to steep areas of the neighbourhood. All these spatial interventions, funded by NGOs and the Municipality of Lima, improved the connectivity of the social dining room in a low consolidated area of the periphery, thus turning it into a second-tier centrality, which provides opportunities for social interaction and development in La Balanza (Vera \& Cuadros, 2016).

\section{Discussion}

The proposed approach to socio-spatial segregation applied here puts forward at least two inter-related issues for discussion. Following Robinson's (2006, p. 164) idea of the 'ordinary' city as "diverse, contested, connected" and the research on post-coloniality (Roy, 2005; Watson, 2006), this sheds more light on the connection between spatial conditions and socio-spatial practices in a highly unequal context where the Western tradition is not enough to explain urban processes.

The lens of 'survivalist creativity' in a context of scarcity, as in the case of nursery schools or collective dining rooms in Valle Amauta and wider Lima, invite a different perspective on economic development (Robinson, 2006). Potential collective development, brought by these activities, is closely related to the characteristics of the urban space that they use and produce, includ-
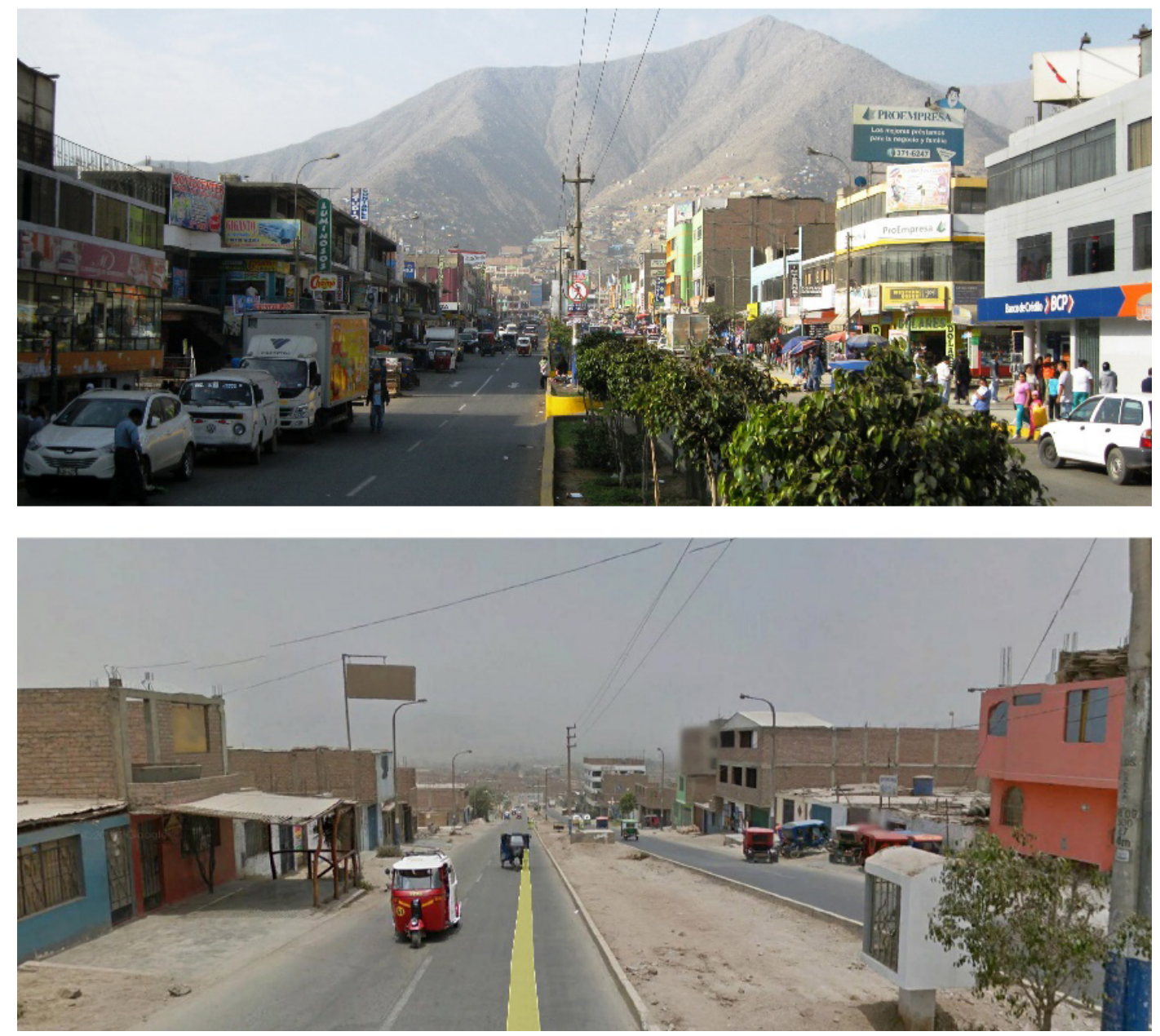

Figure 9. Comparison between central areas in Huaycán (top) and Horacio Zevallos (bottom). Source: Authors and Google Street View (in 2013). 
ing material scarcity, low consolidation, and collective land tenure ship. Spatial isolation or opportunities for connectivity across space are closely related to social and economic activities and the specific spatial conditions in which these activities take place. Our empirical evidence provides insight into how relationships of opportunity emerge, provided by relationships between formal and informal practices and their connections and overlaps in space, also in deprived areas which appear segregated. Intrinsic spatial characteristics from areas developed outside of the norm, such as negotiated borders (McCartney \& Krishnamurthy, 2018) or left-over spaces used by collective activities, such as schools, public spaces or community services, enable opportunities to increase connectivity to these services and further attract complementary activities. This is in line with Robinson's (2006, p. 160) argument that, "cities enable opportunities for frequent interactions and sustained relationships amongst economic agents and social groups, both within and even across 'segregated' spaces and relationships."

However, our findings also challenge the current policy approach to socio-spatial segregation developed and applied in many cities of the Global South, having a focus on informality and land regularisation as a mechanism to create opportunities to reduce socio-spatial segregation. The analysis of Valle Amauta shows how the interrelations between socio-economic activities and specific spatial characteristics provide opportunities to reduce the negative effects of segregation, regardless of whether they are in areas labelled as 'informal' or 'formal.' The opportunities provided by schools, hotels, hardware shops and community activities are tangible examples of this. Planning and policies which tackle socio-spatial segregation could benefit from shifting their focus to socioeconomic and spatial connectivity rather than formalisation of land and property (Figure 1).

Nevertheless, this does not, per se, grant fair access to these opportunities. Centrality and integration in the street network used by hardware shops or hotels to locate themselves in space and take advantage of economic opportunities, only create profit for individual landowners. Benefits are rarely distributed fairly across the neighbourhood or the city. A permissive approach to alternative 'everyday' urban practices could enable participative service delivery and build 'ordinary' cities (Robinson, 2006), but not necessarily fair cities. Under Fainstein's (2011) premise on the fair city, regulation and policy should provide equitable outcomes, benefiting the collectivity and, especially, those who are in the worst situation. Thus, who is profiting from the opportunities created and how to redistribute benefits more fairly must be discussed. In a socio-spatial reality of 'deep difference' (Watson, 2006) and a weak public sector, policies may also propose alternative mechanisms to foster redistribution of benefits beyond the idea of a strong State, predominant in Western societies. Community activities, like the ones observed in Valle Amauta or the case in La Balanza, demonstrate how redistribution is not only brought but also perceived as more legitimate (García Naranjo, 1992) when provided by recognised civil society groups, such as those of the organised women who manage social dining rooms.

\section{Conclusion}

The evidence presented in this article challenges the current focus on informality and land regularisation as a mechanism to tackle socio-spatial segregation. The analysis of Valle Amauta shows how the interrelations between socio-economic activities and specific spatial characteristics provide opportunities to reduce the negative effects of segregation both in what is labelled in the planning discourse as 'informal' and 'formal' areas.

Our research indicates a clear opportunity for future research on how urban policy in contexts like Valle Amauta could take advantage of the development process already happening instead of importing policies from cities in Western contexts, thus, looking for ways to amplify and redistribute opportunities, connecting the efforts and potentials of civil society and both the formal and informal branches of the private sector.

The limitation of this research is that the lens under which the spatial characteristics that enable socioeconomic activities are observed, depends on local cultural and social norms, making it difficult to directly transfer policies from one place to another. However, this also presents opportunities for further research, across different scales and contexts, on the relation between local cultural contexts and the way in which the spatial form of deprived neighbourhoods creates or restricts access to opportunities.

In sum, this article provides a new perspective to understand and tackle segregation, thus offering new insights for planning practice and theory in the Global South. By focusing on land regularisation and using imported solutions, planners in many cities dismiss the real potential of space and society in their local contexts, overlooking chances to reduce socio-spatial segregation.

\section{Acknowledgments}

The analysis of Valle Amauta was possible thanks to the cadaster data provided by the Municipality of Ate. We would like to thank the Urban Development Area of the Municipality of Ate for their support, as well as the numerous people that we have worked with in Valle Amauta, Huaycán and many other areas in Lima, especially Federico Godiño and Pedro Sulca, for their firsthand knowledge and reflections. We would also like to thank the editors and the reviewers for their constructive comments.

\section{Conflict of Interests}

The authors declare no conflict of interests. 


\section{References}

Aguilar, A. G., \& Mateos, P. (2011). Diferenciación sociodemográfica del espacio urbano de la Ciudad de México [Socio-demographic diferentiation of urban space in Mexico City]. EURE, 37(110), 5-30.

Berghauser Pont, M., Stavroulaki, G., Bobkova, E., Gil, J., Marcus, L., Olsson, J., . . . Legeby, A. (2019). The spatial distribution and frequency of street, plot and building types across five European cities. Environment and Planning B: Urban Analytics and City Science, 46(7), 1226-1242. https://doi.org/10.1177/ 2399808319857450

Bosio, M., \& Renteria, S. (1985). El Ermitaño. Historia de una invasión 1962-1986 [El Ermitaño. History of a squatter settlement; Brochure]. Lima: Proceso Social.

Calderón, J. (2014). Miradas, enfoques y estudios sobre las ciudades [Views, approaches, and studies about cities]. Lima: Vicio Perpetuo, Vicio Perfecto.

Calderón, J. (2016). La ciudad ilegal [The illegal city] (2nd ed.). Lima: Punto Cardinal.

Castells, M. (1977). The urban question: A Marxist approach. Cambridge, MA: MIT Press.

Chiaradia, A., Hillier, B., Schwander, C., \& Wedderburn, M. (2009). Spatial centrality, economic vitality/viability. Compositional and spatial effects in Greater London. In D. Koch, L. Marcus, \& J. Steen (Eds.), Proceedings of the 7th international space syntax symposium. Retrieved from https://discovery.ucl. ac.uk/id/eprint/18603

Congreso de la República del Perú. (2006). Decreto legislativo que modifica el decreto legislativo 803, ley de promoción del acceso a la propiedad formal y que dicta medidas complementarias de acceso a la propiedad [Legislative decree that modifies the legislative decree 803, Law for the promotion of access to formal property and that dictates complementary measures to access property] (DL 1202). Lima

Congreso de la República del Perú. (2015). Ley de desarrollo y complementaria de formalización de la propiedad informal, acceso al suelo y dotación de servicios básicos [Development and complementary law for informal property formalisation, access to land, and basic services provision] (Ley 28687). Lima: Congreso de la República del Perú.

Delgado, A., Peek, O., \& d’Auria, V. (2019). Guayaquil. Conflicting competences in Guayaquil's contested and (in)formal periphery. In R. Rocco \& J. van Ballegooijen (Eds.), Routledge handbook of informal urbanization (pp. 100-111). London: Routledge.

Dollfus, O. (1991). Territorios andinos: Reto y memoria [Andean territories: Challenge and memory]. Lima : Institut français d'études andines. https://doi.org/ 10.4000/books.ifea.1836

Espinoza, A., \& Fort, R. (2017). Inversión sin planificación. La calidad de la inversión pública en los barrios vulnerables de Lima [Investment without planning. The quality of public investment in vulnerable neighbour- hoods of Lima]. Lima: GRADE.

Fainstein, S. S. (2011). The just city. London and Ithaca, NY: Cornell University Press.

Fernández-Maldonado, A. M. (2015). Las barriadas de Lima como estímulo a la reflexión urbana sobre la vivienda. Revisitando a Turner y de Soto [The barriadas of Lima as incentive to urban housing reflection. Revisiting Turner and de Soto]. Revista de Estudios sobre Vivienda, 2(3), 18-24.

Fernández de Córdova, G., Fernández-Maldonado, A. M., \& del Pozo, J. M. (2016). Recent changes in the patterns of socio-spatial segregation in Metropolitan Lima. Habitat International, 54, 28-39. https://doi. org/10.1016/j.habitatint.2015.08.016

Figari, E. (1986). Huaycán. Una experiencia de gestión democrática e Innovación tecnológica para la vivienda popular [Huaycán. A democratic management and technologic innovation experience in social housing]. Lima: Universidad Nacional de Ingeniería.

García Naranjo, A. (1992). La experiencia del vaso de leche 1981-1991 [The 'Vaso de leche' experience 1981-1991]. Lima: Fundación Friedrich Ebert.

Giffinger, R. (1998). Segregation in Vienna: Impacts of market barriers and rent regulations. Urban Studies, 35(10), 1791-1812.

Godiño, F., \& Sulca, P. (2017). Interview with Luis Rodríguez and Pablo Muñoz. In L. Rodríguez \& P. Muñoz (Eds.), La ciudad de las laderas. Workshop Limápolis 2016 [The city of the slopes. Limapolis Workshop 2016] (pp. 122-130). Lima: Municipalidad de Ate and PUCP.

Golda-Pongratz, K. (2007). Inside out, outside in: Dependencias recíprocas y adaptaciones de centro y periferia en Lima Metropolitana [Reciprocal dependencies and adaptations of centre and periphery in Metropolitan Lima]. In F. Carrión (Ed.), Perú: La construcción sociocultural del espacio territorial y sus centralidades [Peru: The socio-cultural construction of the territorial space and its centralities]. Quito: OLACCHI.

Habraken, N. J. (2000). The structure of the ordinary. Form and control in the built environment. Cambridge, MA: MIT Press.

Hausleitner, B., \& Berghauser Pont, M. (2017). Development of a configurational typology for microbusinesses integrating geometric and configurational variables. In Proceedings of the 11th International Space Syntax Symposium (pp. 66.1-66.14). Lisbon: Instituto Superior Técnico.

Herrle, P., \& Fokdal, J. (2011). Beyond the urban informality discourse: Negotiating power, legitimacy and resources. Geographische Zeitschrift, 99(1), 3-15.

Hillier, B., \& Hanson, J. (1984). The social logic of space. Cambridge: Cambridge University Press.

Hillier, B. (1996). Space is the machine. Cambridge: Cambridge University Press.

Hillier, B., \& lida, S. (2005). Network and psychological ef- 
fects in urban movement. In A. G. Cohn \& D. M. Mark (Eds.), COSIT 2005, LNCS 3693 (pp. 475-490). Berlin and Heidelberg: Springer.

Instituto Nacional de Estadística e Informática. (2016). Planos estratificados de Lima Metropolitana a nível de manzana [Stratified maps of Metropolitan Lima on the block scale] (Report). Lima: INE.

Instituto Nacional de Estadística e Informática. (2019). Sistema de Información Geográfica para Emprendedores [Entrepreneurs geographic information system; Database]. Instituto Nacional de Estadística e Informática. Retrieved from http://sige.inei.gob.pe/ sige

International Labour Office. (1972). Employment, incomes and equality: A strategy for increasing productive employment in Kenya. Geneva: ILO.

Kropf, K. (2009). Aspects of urban form. Urban Morphology, 13(2), 105-120.

Malengreau, J. (1992). Espacios institucionales en los Andes [Intitutional spaces in the Andes]. Lima: IEP ediciones.

Marcuse, P. (1997). The enclave, the citadel, the ghetto. Urban Affairs Review, 33(2) 228-264. https://doi. org/10.1177\%2F107808749703300206

Matos, J. (2012). Perú, Estado desbordado y sociedad nacional emergente [Peru, overwhelmed state and emerging national society]. Lima: Universidad Ricardo Palma/Editorial Universitaria.

McCartney, S. (2012). At the limit: Vulnerable morphologies in urban areas. Cambridge, MA: Harvard University Press.

McCartney, S., \& Krishnamurthy, S. (2018). Neglected? Strengthening the morphological study of informal Settlements. SAGE Open, 8(1), 1-11. https://doi.org/ $10.1177 / 2158244018760375$

Ministry of Education of Peru. (2019). Estadística de la calidad educativa: Mapa de escuelas [Statistics on education quality: Schools map; Database). ESCALEEstadística de la Calidad Educativa. Retrieved from http://escale.minedu.gob.pe/mapas

Ministry of Environment of Peru. (2019). Geoservidor [Database]. Geoservidor Peru. Retrieved from http://geoservidorperu.minam.gob.pe/geoservidor/ download_raster.aspx

Municipality of Ate. (2016). GIS Cadaster [Database]. Municipality of Ate: The Urban Development Area.

Municipality of Lima. (2013a). Plan metropolitano de desarrollo urbano de Lima y Callao 2035 [Metropolitan Plan for urban development in Lima and Callao 2035]. Lima: Municipality of Lima.

Municipality of Lima. (2013b). PUI Valle Amauta (Report). Lima: Barrio Mío Program.

Muñoz Unceta, P. (2019). Looking for alternatives in the city of the slopes (Unpublished Master thesis). Faculty of Architecture and the Built Environment, TU Delft, the Netherlands.

Open Street Map. (2019). Main street network for Lima [Database]. Open Street Map. Retrieved from https://www.openstreetmap.org

PST Documentation (vs. 3.1.3) [Software]. (2019). Stockholm and Gothenburg: KTH Stockholm, Chalmers School of Architecture and Spacescape AB. Retrieved from https://www.smog.chalmers.se/pst

Robinson, J. (2006). Ordinary cities. Between modernity and development. Oxford: Routledge.

Roy, A. (2005). Urban informality: Toward an epistemology of planning. Journal of the American Planning Association, 71(2), 147-158.

Ruiz-Tagle, J. (2016). La persistencia de la segregación y la desigualdad en barrios socialmente diversos: Un estudio de caso en La Florida, Santiago [Persistence on segregation and inequality in socially diverse neighbourhoods: A case study in La Florida, Santiago]. EURE, 42(125), 81-108.

Sabatini, F. (2006). The social spatial segregation in the cities of Latin America. Washington, DC: Inter-American Development Bank, Sustainable Development Department, Social Programs Division. Retrieved from https://publications.iadb.org/en/ publication/social-spatial-segregation-cities-latinamerica

Salcedo, R. (2010). The last slum: Moving from illegal settlements to subsidized home ownership in Chile. Urban Affairs Review, 46(1), 90-118. https://doi.org/ $10.1177 / 1078087410368487$

Scheer, B. C. (2016). The epistemology of urban morphology. Urban Morphology, 20(1), 5-17.

Sevtsuk, A. (2010). Path and place: A study of urban geometry and retail activity in Cambridge and Somerville, MA (Unpublished Doctoral dissertation). Department of Urban Studies \& Planning, Massachusetts Institute of Technology, USA.

Siksna, A. (1997). The effect of block size and form in North American and Australian centres. Urban Morphology, 1, 19-33.

Smets, P., \& Salman, T. (2016). The multi-layered-ness of urban segregation: On the simultaneous inclusion and exclusion in Latin American cities. Habitat International, 54(1), 80-87. https://doi.org/10.1016/ j.habitatint.2015.08.013

Soja, E. W. (2013). Seeking spatial justice. Minneapolis, $\mathrm{MN}$ : University of Minnesota Press.

van Nes, A. (2005). Typology of shopping areas in Amsterdam. In A. van Nes (Ed.), Space syntax 5th international symposium proceedings (pp. 175-185). Amsterdam: Techne Press.

Vera, J., \& Cuadros, E. (2016). Proyecto Fitekantropus [Fitekantropus Project]. Arkinka, 247, 64-67.

Vernez Moudon, A. (1992). A catholic approach to organising what urban designers should know. Journal of Planning Literature, 4, 331-349.

Vernez Moudon, A. (1997). Urban morphology as an emerging interdisciplinary field. Urban Morphology, 1, 3-10. https://doi.org/10.1111/j.1469-8137.1956. tb05265.x

Watson, V. (2006). Deep difference: Diversity, planning 
and ethics. Planning Theory, 5(1), 31-50. https://doi. org/10.1177/1473095206061020

Watson, V. (2016). Seeing from the South: Refocusing urban planning on the Globe's central urban issues. Urban Studies, 46(11), 2259-2275. https://doi.org/
10.1177/0042098009342598

Whitehand, J. W. R. (2001). British urban morphology: the Conzenian tradition. Urban Morphology, 5(2), 103-109.

\section{About the Authors}
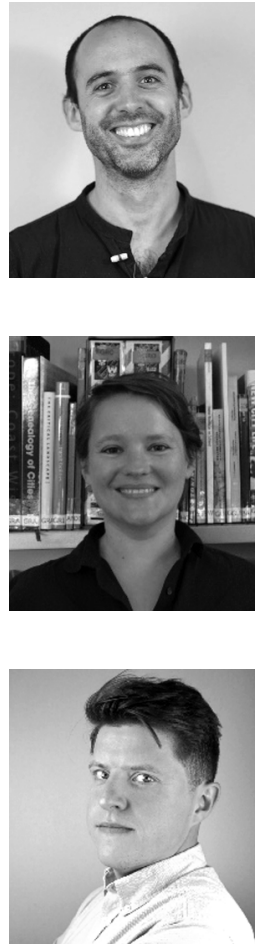

Pablo Muñoz Unceta is a Researcher at the Institute for Advance Architecture of Catalonia in Barcelona, where he carries out research on collaborative governance and circular economy. His background is in architecture and urban planning and design. He holds a MSc degree from the European Post-Master of Urbanism at TU Delft. He has professional experience in Latin America and Europe in different projects and institutions on participatory planning, social housing and slum upgrading programs. His research interests include housing policies, morphological studies, spatial justice, governance models and circular economy.

Birgit Hausleitner is Docent and Researcher at the Chair Urban Design-Theory and Methods in the Department of Urbanism, Faculty of Architecture and the Built Environment, TU Delft. She has a background as an architect and urbanist and conducts research and teaches in the field of urban design. Her research comprises work on mixed-use cities, urban manufacturing and the urban morphological and socio-spatial conditions that facilitate, introduce or improve, combinations of living and working. Moreover, she is involved in developing multi-scalar analytic methods, as well as multi-scalar and multi-actor design instruments.

Marcin Dąbrowski (PhD) is an Assistant Professor at the Chair of Spatial Planning and Strategy in the Department of Urbanism, Faculty of Architecture and the Built Environment, TU Delft, where he conducts research and teaches in the fields of spatial planning and territorial governance. He has a background in political science and regional studies, however, his research interest spans across many topics related to the governance of territory, from regional strategies to circular economy, or energy transition, to regional development policies, governance of urban climate change adaptation, stakeholder engagement in planning, and the evolution of spatial planning systems. 